\title{
Human mercury exposure and health risks in China
}

\author{
XINBIN Feng ${ }^{1,2}$, Bo WANG ${ }^{1,3}$, PING Li $^{1,2}$ \\ ${ }^{1}$ State Key Laboeaotry of Environmental Geochemistry, \\ Institute of Geocheistry, Chinese Academy of Sciences, \\ Guiyang 550081, fengxinbin@mail.gyig.ac.cn \\ ${ }^{2}$ CAS Center for Excellence in Quaternary Science and \\ Global Change, Xi'an, 710061, China \\ ${ }^{3}$ University of Chinese Academy of Sciences, Beijing, \\ 100049, China
}

Methylmercury ( $\mathrm{MeHg}$ ) exposure can lead to adverse impacts on human beings. Previous studies confirmed that fish and rice consumption are the main pathways of human $\mathrm{MeHg}$ exposure. To evaluate the health risks of human mercury $(\mathrm{Hg})$ exposure in China, we selected four typical $\mathrm{Hg}$ contaminated areas and four aquatic food production and coastal areas for this study. Aquatic food products, rice, and human hair samples were collected for total mercury $(\mathrm{THg})$ and $\mathrm{MeHg}$ analysis to evaluate human mercury exposure levels. Generally, rice and fish samples indicated relative low $\mathrm{Hg}$ levels except rice samples collected from Wanshan $\mathrm{Hg}$ Mining Area. Hair $\mathrm{THg}$ concentrations in typical $\mathrm{Hg}$ contaminated areas averaged at $0.33 \mu \mathrm{g} / \mathrm{g}(0.10-2.92 \mu \mathrm{g} / \mathrm{g}$, $\mathrm{n}=144), 0.22 \mu \mathrm{g} / \mathrm{g}(0.08-11.9 \mu \mathrm{g} / \mathrm{g}, \mathrm{n}=156), 0.61 \mu \mathrm{g} / \mathrm{g}(0.13-$ $1.82 \mu \mathrm{g} / \mathrm{g}, \mathrm{n}=125)$, and $2.23 \mu \mathrm{g} / \mathrm{g}(0.41-34.1 \mu \mathrm{g} / \mathrm{g}, \mathrm{n}=168)$ in Gold Mining Area, Coal-fired Power Plant Area, Zinc Smelting Area, and Wanshan $\mathrm{Hg}$ Mining Area, respectively. Hair $\mathrm{THg}$ concentrations averaged at $0.39 \mu \mathrm{g} / \mathrm{g}(0.09-2.24$ $\mu \mathrm{g} / \mathrm{g}, \mathrm{n}=137), 0.45 \mu \mathrm{g} / \mathrm{g}(0.05-5.40 \mu \mathrm{g} / \mathrm{g}, \mathrm{n}=150), 0.81 \mu \mathrm{g} / \mathrm{g}$ $(0.11-9.18 \mu \mathrm{g} / \mathrm{g}, \mathrm{n}=160), 1.37 \mu \mathrm{g} / \mathrm{g}(0.13-29.7 \mu \mathrm{g} / \mathrm{g}, \mathrm{n}=142)$ in Wuhan, Qingdao, Xiamen, and Zhoushan City, respectively. Hair $\mathrm{THg}$ concentrations were significantly elevated in Wanshan $\mathrm{Hg}$ Mining Area and Zhoushan Island, and the average values exceeded USEPA reference limit of $1 \mu \mathrm{g} / \mathrm{g}$. In the coastal area, fish consumption is the main route of human $\mathrm{MeHg}$ exposure. However, the relative contribution of human $\mathrm{MeHg}$ exposure from rice consumption increased significantly from coastal to inland area. Diet structure has a significant effect on the pathways of $\mathrm{MeHg}$ exposure. In conclusion, the population in coastal area with large fish consumption and the population in $\mathrm{Hg}$ contaminated areas have health risks of $\mathrm{MeHg}$ exposure. 